\title{
CARDIOVASCULAR EFFECTS OF 16 WEEKS OF MARTIAL ARTS TRAINING IN ADOLESCENTS
}

\author{
EFEITOS CARDIOVASCULARES DE 16 SEMANAS DE TREINAMENTO DE ARTES \\ MARCIAISEM ADOLESCENTES
}

Original Article

ARtigo Original

Artículo Original

\section{EFECTOS CARDIOVASCULARES DE 16 SEMANAS DE ENTRENAMIENTO DEARTES MARCIALESEN ADOLESCENTES}

\begin{abstract}
Bruna Thamyres Ciccotti Saraiva' ${ }^{1}$ (Physical Education Professional) Raphael Mendes Ritti-Dias ${ }^{2}$ (Physical Education Professional) Breno Quintela Farah ${ }^{3}$ (Physical Education Professional) Vinícius Yukio Botelho Suetake ${ }^{1}$ (Physical Education Professional) Tiego Aparecido Diniz ${ }^{4}$ (Physical Education Professional) Paulo Costa Júnior ${ }^{1}$

(Physical Education Professional) Vinícius Flávio Milanez ${ }^{5}$ (Physical Education Professional) Diego Giulliano Destro Christofaro (Physical Education Professional)
\end{abstract}

1. Universidade Estadual Paulista (UNESP), Faculdade de Ciências e Tecnologia, Department of Physical Education, Presidente Prudente, SP, Brazil.

2. Hospital Israelita Albert Einstein, Department of Physical Education, São Paulo, SP, Brazil. 3. Universidade de Pernambuco (UPE), Department of Physical Education, Pernambuco, PE, Brazil. 4. Universidade de São Paulo (USP), Department of Physical Education, São Paulo, SP, Brazil.

5. Universidade do Oeste Paulista (UNOESTE), Department of Physical Education, Presidente Prudente, SP, Brazil.

\section{Correspondence:}

Departamento de Educação Física, Universidade Estadual (UNESP),

Faculdade de Tecnologia e Ciências. Rua Roberto Simonsen, 305, Presidente Prudente, SP, Brazil. 19060-900.

brunatcsaraiva@gmail.com

\begin{abstract}
Introduction: Sedentary habits increase the chances of developing cardiovascular disease. Physical activity is one of the means of prevention and treatment of these diseases, thus martial arts represent a dynamic option in promoting physical activity. Objective: The objective of the study is analyze the effects of 16 weeks of Martial Arts (Muay Thai or judo) training on cardiovascular variables in adolescents. Methods: The sample consisted of 40 adolescents, aged 11 to 14 years, divided into two groups: Martial Arts ( $n=28)$ and control $(n=12)$. Weight and height measurements were taken to calculate body mass index. Systolic and diastolic blood pressure (BP), heart rate (HR) at rest, pulse pressure (PP) and rate-pressure product (RPP), were also measured. The intervention was carried out through Martial Arts (Muay Thai and judo) training held twice a week for 90 minutes, over 16 weeks. The control group did not undergo any training. The statistical analysis was performed using the following tests: Shapiro-Wilks, Levene's, analysis of covariance (ANCOVA), eta-squared effect size and the net-effect, using SPSS 15.0 software and a significance level of 5\%. Results: There was no statistical difference between the control and Martial Arts groups for the sample characterization. There was a significant difference in systolic BP in the Martial Arts group when compared with the control group ( $p$-value=0.049). The effect size can be considered moderate (effect size $=0.163$ ), with a good net-effect $(3.4 \mathrm{mmHg}$ ). Conclusion: This study showed that 16 weeks of Martial Arts decreased systolic BP in normotensive adolescents. Level of Evidence Il; Therapeutic studies - Investigating the results of treatment.
\end{abstract}

Keywords: Heart rate; Adolescent; Blood pressure; Pulse pressure; Martial arts; Arterial pressure.

\section{RESUMO}

Introdução: Os hábitos sedentários aumentam as chances de desenvolvimento de doenças cardiovasculares. A atividade física é um dos meios de prevenção e tratamento dessas doenças, sendo assim, as artes marciais aparecem como uma opção de caráter dinâmico no incentivo à prática de atividades físicas. Objetivos: O objetivo do estudo consiste em analisar os efeitos de 16 semanas de treinamento de artes marciais (Muay Thai ou Judô) sobre as variáveis cardiovasculares nos adolescentes. Métodos: A amostra foi constituída por 40 adolescentes de 11 a 14 anos, divididos em dois grupos: artes marciais $(n=28)$ e controle $(n=12)$. As medições de peso e altura foram realizadas para o cálculo do índice de massa corporal. Foram medidas também a pressão arterial sistólica e diastólica (PA), a frequência cardíaca (FC) em repouso, a pressão de pulso (PP) e o duplo produto (DP). A intervenção foi realizada através da prática de artes marciais (Muay Thai e Judô), realizada duas vezes por semana, durante 90 minutos, por 16 semanas. O grupo controle não realizou nenhum tipo de treinamento. A análise estatística foi feita utilizando os seguintes testes: Shapiro-Wilks, Levene, análise de covariância (ANCOVA), tamanho do efeito eta-squared e efeito líquido, utilizando o software SPSS 15.0 e nivel de significância de 5\%. Resultados: Não houve diferença estatística entre o grupo controle e o grupo de artes marciais para a caracterização da amostra. Houve diferença significativa na PA sistólica no grupo de artes marciais quando comparado com o grupo controle (valor $p=0,049$ ). A dimensão do efeito pode ser considerada moderada (dimensão do efeito $=0,163)$, com um bom efeito líquido $(3,4 \mathrm{mmHg})$. Conclusão: Este estudo demonstrou que 16 semanas de artes marciais diminuíram a PA sistólica em adolescentes normotensos. Nível de Evidência ll; Estudos terapêuticos - Investigação dos resultados do tratamento.

Descritores: Frequência cardíaca; Adolescente; Pressão sanguínea; Pressão de pulso; Artes marciais; Pressão arterial.

\section{RESUMEN}

Introducción: Los hábitos sedentarios aumentan las posibilidades de desarrollo de enfermedades cardiovasculares. La actividad física es uno de los medios de prevención y tratamiento de esas enfermedades, siendo así, las artes marciales aparecen como una opción de carácter dinámico en el incentivo a la práctica de actividades físicas. Objetivos: El objetivo del estudio es analizar los efectos de 16 semanas de entrenamiento de artes marciales (Muay Thai o Judo) sobre las variables cardiovasculares en adolescentes. Métodos: La muestra fue constituida de 40 adolescentes de 11 a 14 años, divididos en dos grupos: artes marciales ( $n=28)$ y control $(n=12)$. Fueron realizadas mediciones de peso y altura para calcular el índice de masa corporal. Fueron medidas también la presión arterial sistólica y diastólica (PA), 
frecuencia cardíaca (FC) en reposo, la presión de pulso (PP) y el doble producto (DB). La intervención fue realizada a través de la práctica de artes marciales (Judo y Muay Thai), realizada dos veces por semana durante 90 minutos, por 16 semanas. El grupo control no realizó ningún tipo de entrenamiento. El análisis estadístico fue hecho usando los siguientes tests; Shapiro-Wilk, Levene, análisis de covarianza (ANCOVA), tamaño de efecto eta-squared y efecto neto, usando el software SPSS 15.0 y el nivel de significación de 5\%. Resultados: No hubo diferencia estadística significativa entre el grupo control y el grupo de artes marciales para la caracterización de la muestra. Hubo diferencia significativa en la PA sistólica en el grupo de artes marciales, cuando comparado con el grupo control ( valor $p=0,049$ ). La dimensión del efecto puede ser considerada moderada (dimensión del efecto=0,163) con un buen efecto neto $(3,4 \mathrm{mmHg}$ ). Conclusión: Este estudio demostró que 16 semanas de artes marciales disminuyeron la PA sistólica en adolescentes normotensos. Nivel de Evidencia Il; Estudios terapéuticos - Investigación de los resultados del tratamiento.

Descriptores: Frecuencia cardíaca; Adolescente; Presión sanguínea; La presión del pulso; Artes marciales; Presión arterial.

\section{INTRODUCTION}

Cardiovascular diseases are the leading causes of deaths worldwide. ${ }^{1}$ Blood pressure is an independent, linear and continuous risk factor for cardiovascular disease. ${ }^{2,3}$ Alterations in blood pressure is a major risk factor for the development of hypertension in the young population, ${ }^{4}$ and given that high blood pressure during adolescence tracks into adulthood, ${ }^{5}$ early therapeutic approaches should be employed in young people.

Martial arts are a popular form of exercise for children and adolescents. ${ }^{6}$ Studies have demonstrated the benefits of Martial Arts for improving physical fitness, ${ }^{7,8}$ performance ${ }^{9-11}$ and bone health. ${ }^{12}$ However, whether Martial Arts can alter the cardiovascular profile is unknown. Given that high intensity exercise potentiates the cardiovascular effects of exercise in young people, ${ }^{13}$ and that martial arts usually have moderate to high intensities, ${ }^{14,15}$ it is possible that this mode of exercise could affect cardiovascular function in this age-group.

Thus, the aim of the present study was to analyze the effects of 16-weeks of martial arts training (Muay-Thai or judo) on cardiovascular variables in adolescents. We hypothesized that martial arts training would improve cardiovascular health in adolescents.

\section{MATERIALS AND METHODS}

This study was developed in a social project in Presidente Prudente-Brazil (Southeastern Brazil), carried out with low income adolescents. This project provides various activities for young people (chess, computer activities and practicing different sports, among others). Adolescents were included if they: (i) were enrolled and participating in the activities of the above mentioned institution; (ii) did not present any serious orthopedic disease that prevented them from performing Martial Arts; (iii) were not taking medication to control blood pressure; (iv) did not have any respiratory illness that prevented them practicing exercise. All participants returned the Informed Consent form signed by parents or guardians giving permission for participation and the study was approved by the Research Ethics Committee of the Universidade Estadual Paulista (Process number: 26702414.0.0000.5402).

Body mass was measured using an electronic scale, Filizola, accurate to $0.1 \mathrm{~kg}$, with a maximum capacity of $150 \mathrm{~kg}$ and height using a fixed stadiometer, Sanny, with a precision of $0.1 \mathrm{~cm}$ and maximum extension of two meters.

Systolic and diastolic blood pressure (BP) were obtained using an automatic blood pressure monitor (brand Omron Healthcare, Inc., IntelliSense, model HEM 742, Omron Corporation, Model HEM 742, Kyoto, Kansai, Japan) with cuffs of appropriate size to the arm circumference of the participants, ${ }^{16}$ obtained on the right side with the arm at a height in line with the heart. The participant remained seated and after resting for approximately 15 minutes the blood pressure was measured. ${ }^{17}$
All BP measurements were performed three times in the right arm and the mean of the final two measures was used for analysis. This blood pressure device has been previously validated for use in adolescents. ${ }^{18}$ Pulse pressure (PP) was defined as the difference between the systolic and diastolic BP readings.

Heart rate (HR) was obtained with a heart rate monitor (Polar FT-1 model T-31 Owncod-coded transmitter, Finland) with the cardiofrequencimeter fixed at the sternum, specifically at the xiphoid process. For the evaluation of resting heart rate the adolescents remained resting for 15 minutes until the assessment was performed. The rate pressure product (RPP) was calculated as the product of HR and systolic BP.

The social project offered leisure activities such as: Judo, Muay-Thai, chess, computer and music to adolescents. The adolescents were divided into two groups: Martial Arts (Judo and Muay-Thai) and Control (chess, computer and music). The Martial Arts group performed 16 weeks of training, after a two week adaptation period. The training was conducted twice a week; each session had a duration of 90 minutes, as recommended by the American College of Sports Medicine Guidelines. ${ }^{19}$ Each session consisted of 15 minutes of stretching, 10 minutes of warming up, 60 minutes of specific martial arts training (as detailed below) and five minutes of cooling down with stretching. Both training programs were of moderate intensity, monitored by the perceived exertion scale. ${ }^{20}$ All the participants were previously familiarized with the use of the RPE scale.

The control group performed other activities twice a week during the 16 weeks. They were instructed to maintain their usual physical activity levels throughout the study.

The judo training was based on the principles of the sport and was characterized as a fight for domain, aiming to grab and hold an opponent. Initially, we developed a series of pre-sport activities. These included games involving the field of the opponent's footprint, conquests for territory using the elements of judo ground fighting, crouching fights, with the goal of unbalancing the opponent, and catching adapted to the sport, practiced in fours and composed of guards and bearings. In addition, specific activities for the improvement of judo techniques were performed. First falls (forward, sideways and backward) and bearings (for right and left) were learnt, followed by incoming blows, which training specific to learning and the correct execution of the blows. In addition, ground game was practiced, which is a struggle carried out on the ground, where the practitioners enhance their immobilization and strangulation techniques. Finally the fight itself was performed, where the individuals used all the above techniques in a single activity.

Muay-Thai training is characterized as a percussion fight, with the aim of striking the opponent to score points. Initially, the training included less complex activities and low intensity for the participants who were familiar with the sport, such as balance activities, striking parts of the 
body, strength, agility, coordination and development of laterality. This progressed to more specific activities, such as kicking, kneeing, punching, elbowing, dodges and defenses, always using equipment and adequate safeguards aimed at the safety of the students.

After learning these specific activities, the process of unification of blows began, with sequences that always used arms and legs to impede movement, in addition to a gradual increase in intensity. After learning the movements and techniques, the students began performing combat simulations with the teachers.

\section{Statistical analysis}

Normality and homogeneity of variance were verified using the ShapiroWilks and Levene's tests, respectively. Sample characterization variables were presented as mean and standard deviation. To compare the cardiovascular effects of the interventions, adjusting for age and sex, analysis of covariance (ANCOVA) was used. The eta-squared effect size and net-effect ( $\triangle$ Martial Arts group - $\triangle$ Control Group) were obtained. The statistical significance was 5\%. The statistical package used in the analyzes was SPSS 15.0

\section{RESULTS}

Seventy adolescents aged 11 to14 years were initially enrolled in the present study. During the intervention period 30 adolescents left the study for exceeding the number of absences or not performing the evaluations (sample loss of $42.8 \%$ ). Thus, the final sample consisted of 40 adolescents (28 boys), divided into Martial Arts ( $n=28$ ) and Control $(n=12)$. (Figure 1)

At baseline, there were no significant differences between the intervention groups regarding anthropometric variables, systolic BP ( $p$-value $=0.259)$, diastolic BP ( $p$-value $=0.437)$, resting HR ( $p$-value $=0.277)$, PP ( $p$-value=0.266) or RPP ( $p$-value=0.208). The sample characteristics are shown in Table 1.

Figure 2 and Figure 3 presents the cardiovascular effects of the interventions. There were significant decreases in systolic BP in the Martial

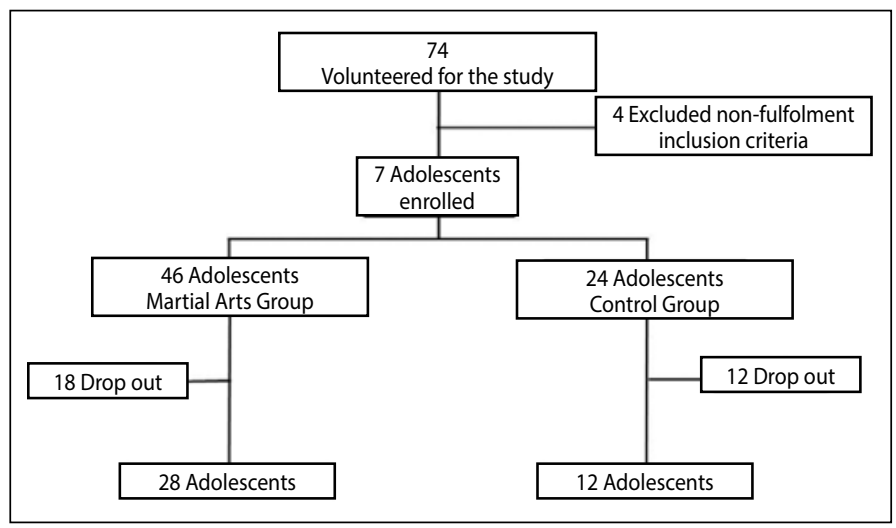

Figure 1. Flow diagram of the sample.

Table 1. Characteristics of the sample according to the group at baseline.

\begin{tabular}{c|c|c|c}
\hline Variables & $\begin{array}{c}\text { Martial arts } \\
(\mathbf{n = 2 8 )}\end{array}$ & $\begin{array}{c}\text { Control } \\
(\mathbf{n = 1 2 )}\end{array}$ & $\boldsymbol{p}$-value \\
\hline Sex (\%boys) & 71.5 & 66.7 & 0.785 \\
\hline Age (years) & $10.9(1.4)$ & $11.0(1.4)$ & 0.110 \\
\hline Weight $(\mathrm{kg})$ & $41.3(13.1)$ & $48.2(14.3)$ & 0.135 \\
\hline Height $(\mathrm{cm})$ & $146.9(10.7)$ & $151.8(11.1)$ & 0.197 \\
\hline Body mass index $\left(\mathrm{kg} / \mathrm{m}^{2}\right)$ & $18.8(4.1)$ & $20.5(4.1)$ & 0.233 \\
\hline Systolic BP $(\mathrm{mmHg})$ & $106.0(7.3)$ & $112.1(16.4)$ & 0.259 \\
\hline Diastolic BP $(\mathrm{mmHg})$ & $59.6(9.4)$ & $62.1(8.0)$ & 0.437 \\
\hline Pulse pressure $(\mathrm{mmHg})$ & $45.96(8.9)$ & $50.00(12.6)$ & 0.266 \\
\hline Heart rate $(\mathrm{bpm})$ & $76.8(11.3)$ & $81.2(12.8)$ & 0.277 \\
\hline Rate pressure product $\left(\mathrm{bpm}{ }^{*} \mathrm{mmHg}\right)$ & $8171.2(1275.7)$ & $9019.8(848.1)$ & 0.208 \\
\hline
\end{tabular}

$\mathrm{BP}=$ Blood pressure, values are presented as mean (Standard deviation) or frequency.
Arts group ( $p$-value<0.05), while the control group presented increases ( $p$-value<0.05). The changes in the Martial Arts group was significantly greater than the control group ( $p$-value=0.049). The effect size for the Eta-squared can be considered as large (effect size $=0.163$ ). There were no significant changes in diastolic BP, resting HR, PP or RPP in either the Martial Arts or control group ( $p$-value>0.05) with a low effect size in both.

\section{DISCUSSION}

The results of this study indicated that 16 weeks of Martial Arts training performed twice a week decreased systolic BP in adolescents. These results suggest that Martial Arts, including Judo and Muay-Thai, can be used to lower BP in young people.

This is the first study to show a reduction in systolic BP following Martial Arts training in adolescents. The strengths of the study include controlling for various potential confounders, the homogeneity of the sample and this being the first study to analyze the effects of martial arts on cardiovascular variables in adolescents. In fact, previous studies ${ }^{21,22}$ that analyzed the effects of Martial Arts on cardiovascular variables were performed in cohorts of either healthy adults or elderly individuals or those with cardiometabolic diseases. In addition, only Tai Chi Chuan has been investigated..$^{23}$ thus, the effects of other Martial Arts, such as Judo and Muay Thai, which are confrontation Martial Arts and the most intense, are unknown.

The present study demonstrated an improvement in systolic BP after 16 weeks of Martial Arts, with a net-effect of $3.4 \mathrm{mmHg}$. These findings demonstrated that Martial Arts, such as Judo and Muay-Thai, are an interesting form of prevention for cardiovascular disease in adolescence, which is interesting given that high blood pressure during adolescence tracks into adulthood ${ }^{5}$. In addition, it is know that a reduction of $2 \mathrm{mmHg}$ in systolic BP results in a $6 \%$ decrease in the risk of stroke and a $4 \%$ reduction in the risk of cardiac heart disease. ${ }^{24}$

Similar findings have been observed in other studies with Martial Arts in adults and the elderly. For example, Lo et al. ${ }^{25}$ found a significant reduction in both systolic and diastolic BP in hypertensive adults after 8 weeks of Tai Chi Chuan training (3 times a week, 60 mins per session). Zheng et al. ${ }^{26}$ in their meta-analytical study with 22 studies, found that Thai Chi Chuan training reduced systolic BP in healthy adults. Similarly, Squarcini et al. ${ }^{21}$ analyzed the benefits of karate practice (3 times a week, 60 minutes, for 3 months) in healthy hypertensive elderly individuals and found that, in addition to other benefits in quality of life, these women significantly decreased systolic blood pressure.

Although it was not been aim of this study to analyze the underlying mechanisms, it can be speculated that there was maintenance or a small increase in cardiac output in the Martial Arts group, whereas in the control group there was an increase in cardiac output, especially through the increase in HR. Comparison with other studies involving adolescents and Martial Arts is limited by the lack of studies. However, a recent meta-analysis observed a small increase in cardiac output (small reduction in heart rate and small increase in stroke volume) after Tai Chi Chuan training in healthy adults. Future studies should be performed to investigate these variables in adolescents.

The non-randomization is the main limitation of this study, which explains in part why the groups were not matched, in addition to the absence of physiological variables to explain the decreases in blood pressure. In addition the analysis considering the martial arts group with judo and muay-thai practitioners in the same group can be considered as a limitation, since these martial arts have their specificities. However, these groups did not differ among themselves and were treated together in comparison with the control group to increase the power of statistical analysis. Finally, this study included only normotensive adolescents; therefore, our data need to be interpreted cautiously and may not be generalizable to 


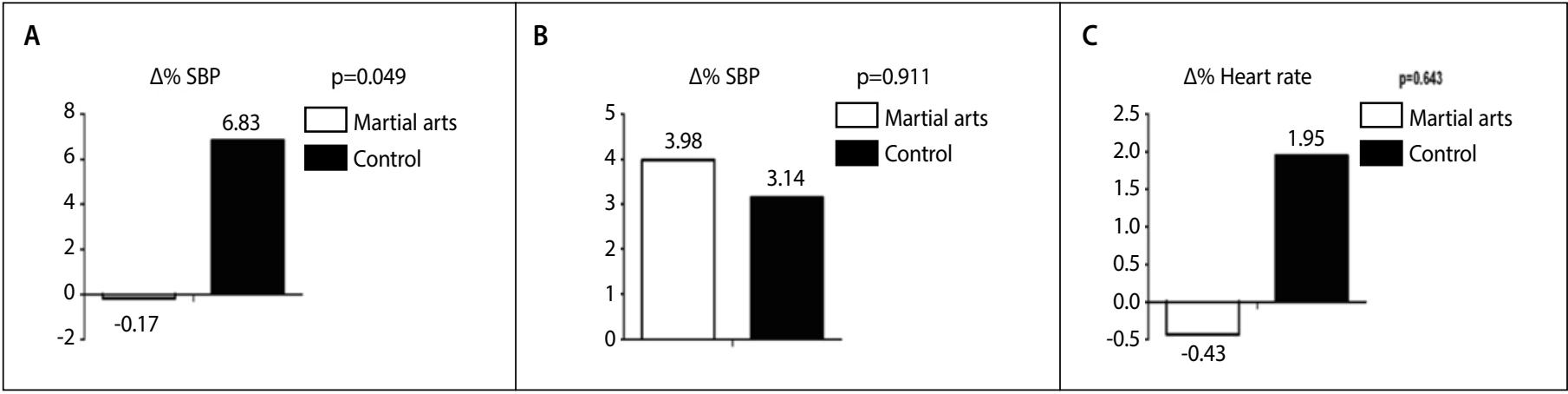

Figure 2. Comparasion of $\triangle \%$ of systolic blood pressure (SBP), diastolic blood pressure (DBP) and heart rate in martial arts and control group. *Adjusted by sex and body mass index (BMI).

A

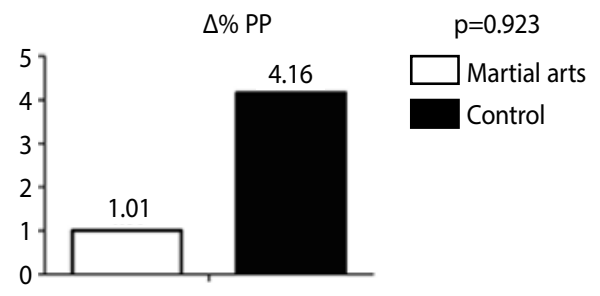

B

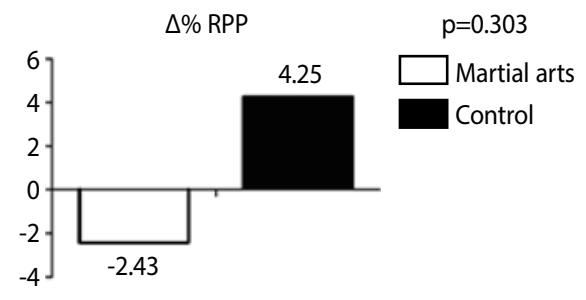

Figure 3. Comparasion of $\triangle \%$ of pulse pressure (PP) and rate pressure product (RPP) in martial arts and control group. *Adjusted by sex and body mass index (BMI). all adolescents; it is possible that the results could have been better in hypertensive adolescents. ${ }^{27}$ Finally, although the participants'ages were tightly controlled, we did not determine the Tanner stage.

\section{CONCLUSION}

In summary, this study showed that 16 weeks of Martial Arts decreased systolic BP in normotensive adolescents. Therefore, Martial Arts could be an alternative mode of physical activity to improve cardiovascular health and prevent cardiovascular diseases in young people.

\section{ACKNOWLEDGMENTS}

The author thank for the subjects who volunteered for this effort, graduate assistants and the University participation, support, and cooperation that made this study possible. No external funding was obtained for this study. The author has no conflict of interest relevant to the content of the article.

All authors declare no potential conflict of interest related to this article.

AUTHORS' CONTRIBUTIONS: Each author made significant individual contributions to this manuscript. BTCS (0000-0002-0902-0433)*: Substantial contribution in the conception and design, instructor in the applied intervention, interpretation of data, writing and review; RMRD (0000-0001-7883-6746)*: and VFM (0000-0002-8121-2616)*: data analysis, writing and review; BQF (0000-0003-2286-5892)*: statistical analysis, writing and review; VYBS (0000-0002-3981-5229)*: instructor in the applied intervention, data collection and analysis, writing and review; TAD (0000-0002-2655-9588** writing and review; PCJ (0000-0002-1448-9607)*: instructor in the applied intervention, intellectual collaboration and creation of the research project; DGDC (0000-0001-9917-9992)*: data analysis, statistical analysis, writing and review, research project coordinator. All authors contributed to the intellectual concept of the study and approved the final version of the manuscript. *ORCID (Open Researcher and Contributor ID).

\section{REFERENCES}

1. Lopez AD, Mathers CD, Ezzati M, Jamison DT, Murray, CJ. Global and regional burden of disease and risk factors, 2001: systematic analysis of population health data. Lancet. 2006;367(9524):1747-57.

2. Christofaro DG, Ritti-Dias RM, Chiolero A, Fernandes RA, Casonatto J, de Oliveira AR. Physical activity is inversely associated with high blood pressure independently of overweight in Brazilian adolescents. Scand J Med Sci Sports. 2013;23(3):317-22.

3. Magliano ES, Guedes LG, Coutinho ES, Bloch KV. Prevalence of arterial hypertension among brazilian adolescents: systematic review and meta-analysis. BMC Public Health. 2013;13:833.

4. Redwine KM, Acosta AA, Poffenbarger T, Portman RJ, Samuls J. Development of hypertension in adolescents with pre-hypertension. J Pediatr. 2012;160(1):98-103.

5. Chen W, Srinivasan SR, Li S, Xu J, Berenson GS. Metabolic syndrome variables at low levels in childhood are beneficially associated with adulthood cardiovascular risk: the Bogalusa Heart Study. Diabetes Care. 2005;28(1):126-31.

6. Vertonghen J, Theeboom M, Pieter W. Mediating factors in martial arts and combat sports: an analysis of the type of martial art, characteristics, and social background of young participants. Percept Mot Skills. 2014;118(1):41-61.

7. Ouergui I, Hssin N, Haddad M, Padulo J, Franchini E, Gmada N, et al. The effects of five weeks of kickboxing training on physical fitness. Muscles Ligaments Tendons J. 2014;4(2):106-13.

8. Liu M, So H. Effects of Tai Chi exercise program on physical fitness, fall related perception and health status in institutionalized elders. Taehan Kanho Hakhoe Chi. 2008;38(4):620-8.

9. Tabben M, Sioud R, Haddad M, Franchini E, Chaouachi A, Coquart, J, et al. Physiological and perceived exertion responses during International Karate Kumite Competition. Asian J Sports Med. 2013;4(4):263-71.

10. Andreato LV, Franchini E, de Moraes SM, Pastório JJ, da Silva DF, Esteves JV, et al. Physiological and technical-tactical analysis in brazilian Jiu-jitsu competition. Asian J Sports Med. 2013;4(2):137-43.

11. Preuschl E, Hassmann M, Baca A. A Kinematic analysis of the jumping Front-leg axe-kick in Taekwondo. J Sports Sci Med. 2016;15(1):92-101

12. Fong SS, Guo X, Cheung AP, Jo AT, Lui GK, Mo DK, et al. Elder Chinese Martial Art practitioners have higher radial bone strength, hand-grip strength, and better standing balance control. ISRN Rehabilitation. 2013;(2013):ID185090.

13. Farah BQ, Ritti-Dias RM, Balagopal PB, Hill JO, Prado WL, et al. Does exercise intensity affect blood pressure and heart rate in obese adolescents? A 6-month multidisciplinary randomized intervention study. Pediatr Obes. 2014;9:111-20.
14. Viveiros L, Costa EC, Moreira A, Nakamura FY, Aoki MS. Monitoramento do treinamento no judô: comparação entre a intensidade da carga planejada pelo técnico e a intensidade percebida pelo atleta. Rev Bras Med Esporte. 2011;17(4):266-9.

15. Brauer Junior AG, dos Santos DD, Silva FF, Pimenta TF, Alves RC. Análise descritiva do treinamento físico de atletas profissionais de Muay Thai. Cad da Esc de Educ e Human. 2015;1(10):14-26.

16. Araújo TL, Lopes MV, Guedes NG, Cavalcante TF, Moreira RP, Chaves ES. Cuff dimension for children and adolescents: a study in a northeastern brazilian city. Rev Lat Am Enfermagem. 2008;16(5):877-82.

17. Sociedade Brasileira de Cardiologia, Sociedade Brasileira de Hipertensão, Sociedade Brasileira de Nefrologia. VI Diretrizes Brasileiras de Hipertensão. Arq Bras Cardiol. 2010;95(1)(Suppl 1):1-51.

18. Christofaro DG, Fernandes RA, Gerage AM, Alves MJ, Polito MD, Oliveira AR. Validation of the Omron HEM 742 blood pressure monitoring device in adolescents. Arq Bras Cardiol. 2009;92(1):10-5.

19. KohrtWM, Blomfield SA, Little KD, Nelson ME, Yingling AR. American College of Sports Medicine: physical activity and bone health. Med Sci Sports Exerc. 2004;36(11):1985-96.

20. Borg G, Hassmén P, Lagerström M. Perceived exertion related to heart rate and blood lactate during arm and leg exercise. Eur J Appl Physiol Occup Physiol. 1987;56(6):679-85.

21. Squarcini CF, da Silva LW, Leite MC, de Souza SB, dos Santos CE, da Silva NM, et al. Benefícios da prática do caratê para pessoas idosas. Revista Kairós de Gerontologia. 2014;17(2):27-42.

22. Faganello JHS. Influência do treinamento do kung fu estilo Garra de Águia na capacidade cardiorrespiratória em adultos. 2015.

23. Nery RM, Zanini M, Ferrari JN, Silva CA, Farias LF, Comel JC, et al. Tai Chi Chuan for cardiac rehabilitation in patients with coronary arterial disease. Arq Bras Cardiol. 2014;102(6):588-92.

24. Whelton PK, He J, Appel LJ, Cutler JA, Havas S, Kotchen TA, et al. Primary prevention of hypertension: clinical and public health advisory from The National High Blood Pressure Education Program. JAMA. 2002;288(15):1882-8.

25. Lo H-M, Yeh C-Y, Chang, S-C, Sung H-C, Smith, GD. A Tai Chi exercise programme improved exercise behaviour and reduced blood pressure in outpatients with hypertension. Int J Nurs Pract. 2012;18(6):545-51.

26. Zhang F, Kong L-L, Zhang Y-Y, Li S-C. Evaluation of impact on health-related quality of life and cost effectiveness of traditional chinese medicine: a systematic review of randomized clinical trials. J Altern Complement Med. 2012;18(12):1108-20.

27. Corrêa Neto VG, Palma A. Impacto da atividade física na hipertensão arterial em adolescentes com sobrepeso e obesidade. ConScientiae Saúde. 2015;14(1):32-9. 